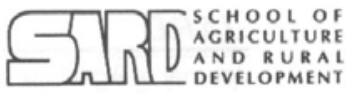

কৃষि ও পল्षী উन्नয়न অनूयদ
Available online at http://www.banglajol.info/index.php/jard
$\mathrm{J}$ ARD

Journal of Agriculture \& Rural Development

\title{
Effect of N P K S Zn and B on Yield Attributes and Yield of French Bean in South Eastern Hilly Region of Bangladesh
}

\author{
M. MoniruZzaman ${ }^{1 *}$, M. R. ISLAM ${ }^{2} \&$ J. HASAN $^{3}$ \\ ${ }^{1}$ Agricultural Research Station, Raikhali, BARI, Chandraghona, Rangamati Hill District-4531, Bangladesh \\ ${ }^{2}$ Regional Agricultural Research Station, Rahmatpur, BARI, Barisal, Bangladesh \\ ${ }^{3}$ Department of Horticulture, Bangabandhu Sheikh Mujibur Rahman Agricultural University, Salna, \\ Gazipur, Bangladesh
}

\begin{abstract}
A field experiment on French bean taking the variety BARI Jhar Shim-2 was conducted with five levels of Nitrogen $\left(0,40,80,120\right.$ and $\left.160 \mathrm{~kg} \mathrm{~N} \mathrm{ha}^{-1}\right)$ and four levels of each of phosphorous $(0,40,80$ and $\left.120 \mathrm{~kg} \mathrm{P}_{2} \mathrm{O}_{5} \mathrm{ha}^{-1}\right)$, potassium $\left(0,30,60\right.$ and $\left.90 \mathrm{~kg} \mathrm{~K}_{2} \mathrm{O} \mathrm{ha} \mathrm{h}^{-1}\right)$ and sulfur $(0,10,20$ and $30 \mathrm{~kg} \mathrm{~S} \mathrm{ha-}$ $\left.{ }^{1}\right)$, three levels of each of zinc $\left(0,4\right.$ and $\left.8 \mathrm{~kg} \mathrm{Zn} \mathrm{ha}^{-1}\right)$ and boron $\left(0,1\right.$ and $\left.1.5 \mathrm{~kg} \mathrm{~B} \mathrm{ha}^{-1}\right)$ at the Agricultural Research Station, Raikhali, Rangamati Hill District during Rabi (winter) seasons of 20052006 and 2006-2007. The experiment was conducted in Randomized Complete Block Design with three replications. Yield and yield components of French bean were significantly influenced by different fertilizer treatments containing macro and micronutrients separately. Results showed significant effect of fertilizers on plant height, number of branches and leaves per plant, pod length, number of green pods and pod weight per plant and green pod yield during both years. The highest pod yield of 23.14 $t$ ha $^{-1}$ (average of 2005-2006 and 2006-2007) was obtained with 120-120-60-20-4-1 $\mathrm{kg}$ of $\mathrm{N}-\mathrm{P}_{2} \mathrm{O}_{5}-\mathrm{K}_{2} \mathrm{O}-\mathrm{S}-\mathrm{Zn}-\mathrm{B}$ plus $0.5 \mathrm{~kg} \mathrm{Mo} \mathrm{ha} \mathrm{a}^{-1}$ along with 10 tons cowdung per hectare that was closely followed by 120-80-60-20-4-1 kg of N-P $\mathrm{P}_{2} \mathrm{O}_{5}-\mathrm{K}_{2} \mathrm{O}-\mathrm{S}-\mathrm{Zn}-\mathrm{B}$ plus $0.5 \mathrm{~kg} \mathrm{Mo} \mathrm{ha-1}$ along with 10 tons cowdung per hectare. The response equations indicated an optimum level of $138.6 \mathrm{~kg} \mathrm{~N}, 131.5$ $\mathrm{kg} \mathrm{P}_{2} \mathrm{O}_{5}, 63.4 \mathrm{~kg} \mathrm{~K}_{2} \mathrm{O}$ and $17.4 \mathrm{~kg} \mathrm{~S} \mathrm{ha}^{-1}$ for higher green fruit yield of French bean. The economic doses of nutrients came out to be 135.8-123.3-60-17.4 kg of N-P $\mathrm{P}_{2} \mathrm{O}_{5}-\mathrm{K}_{2} \mathrm{O}-\mathrm{S} \mathrm{ha}{ }^{-1}$. Application of 136123-60-17-4-1 kg N-P $\mathrm{O}_{2} \mathrm{O}_{5}-\mathrm{K}_{2} \mathrm{O}-\mathrm{S}-\mathrm{Zn}-\mathrm{B}$ plus $0.5 \mathrm{~kg}$ Mo ha ${ }^{-1}$ along with 10 tons cowdung per hectare might be considered as profitable dose for growing French bean in South-Eastern hilly region of Bangladesh.
\end{abstract}

Key words: Legume, French bean, Rabi, Rangamati, Rhizobium, AEZ-29, physiological maturation.

\section{INTRODUCTION}

French bean (Phaseolus vulgaris L.) is an important legume vegetable grown during the rabi season for its tender green pods which form a rich source of protein, calcium and iron. Two French bean varieties (BARI Jhar Shim-1 and BARI Jhar Shim-2) for winter (rabi) season have been developed by Bangladesh Agricultural Research Institute (BARI). French bean (bush type) withdraws $80 \mathrm{~kg} \mathrm{~N}, 30 \mathrm{~kg} \mathrm{P}_{2} \mathrm{O}_{5}$ and $100 \mathrm{~kg} \mathrm{~K}_{2} \mathrm{O}$ from the soil for producing $12.0 \mathrm{t} \mathrm{ha}^{-1}$ green pods (AVRDC, 1990). The requirement of fertilizer for any crop varies with the cultivars and soil types in

* Corresponding author: SSO (Hort.), ARS, Raikhali, BARI, Chandraghona, Rangamati Hill District-4531, Mobile: 01819-698843

(C) 2008 School of Agriculture and Rural Development, Bangladesh Open University, All rights reserved. 


\section{Moniruzzaman et al.}

agro-ecological zones (Mitra et al., 1990). Being a shy nodulator, French bean crop readily responds to large doses of Nitrogen and optimum Nitrogen was as high as $125.6 \mathrm{~kg} \mathrm{ha}^{-1}$ (Srinivas and Naik, 1990). Ivanove et al (1987) reported that the pod yield of French bean was increased with the increase nitrogen levels up to $150 \mathrm{~kg} \mathrm{ha}^{1}$. Short growth cycle of this crop is one of the reasons that Nitrogen fixation is not as efficient as other legumes because carbohydrate production by the French bean plant occurs at the same time as the plants and the rhizobium needs a maximum carbohydrate supply and there is a heavy competition for Carbohydrate between the bacteria and French bean (Van Schoonhaven and Voysests, 1991). This crop responds to the application of phosphorous more and production increases with the increasing Phosphorous doses because with Phosphorous fertilizer, the plant develops its roots better and increases penetration with a better root system of deeper penetration and thus absorbs more Phosphorus which the bean plants need up to the physiological maturation phase (Malavolta, 1972) and optimum Phosphorus level was found to be as high as $123 \mathrm{~kg} \mathrm{ha}^{-1}$ ) (Srinivas and Rao, 1984). There are reports that Potassium deficiency symptoms are hard to absorb and the deficiency in bean plant occurs without being noticed by the farmers and hence all fertilizer recommendations always include potassium nutrients (Van Schoonhaven and Voysests, 1991). French bean can absorb sulfur in great quantities and it is necessary to maintain the relation of nitrogen and sulfur in the plant to produce protein (Hendrix, 1967) and application of $S$ between $10-20 \mathrm{~kg} \mathrm{ha}^{-1}$ can control sulfur deficiency (Van Schoonhaven and Voysests, 1991). It is reported that among the most important food crops, French bean crops are the most responsive to all micronutrient application and they have a higher response to zinc but lower response to boron (Lucas and Knezek, 1972). Boron and sulfur deficiency can be controlled by soil application of $1 \mathrm{~kg} \mathrm{~B} \mathrm{ha}^{-1}$ and $25 \mathrm{~kg} \mathrm{ZnSo}_{4} \mathrm{ha}^{-1}$ (6-9 kg ha $\mathrm{kg}^{-1}$ (Parthosharothi, 1999). A combined nutrition of N, P, K, S and micronutrient is always beneficial for increasing yield of French bean. Despite evidence of benefits of fertilization, very little work has so far been done on the use of N, P, K, S, Zn and B in French bean in Bangladesh. The present investigation was, therefore, undertaken to evaluate the effects of $\mathrm{N}, \mathrm{P}, \mathrm{K}, \mathrm{S}, \mathrm{Zn}$ and $\mathrm{B}$ at different levels on the growth and yield of French bean in the South-Eastern Hilly region of Bangladesh.

\section{MATERIALS AND METHODS}

The experiment was conducted at the Agricultural Research Station, Raikhali in the district of Rangamati during the Rabi (winter) seasons of 2005-2006 and 2006-2007 using French bean var. BARI French bean-2. The experimental field belongs to AEZ-29. Texturally the soil is sandy clay loam. Particle size was determined by hydrometer method and other characteristics were determined by Agro Services International (ASI) method (Hunter, 1984). The initial soil analysis result is shown in Table 1 . There were 19 treatment combinations consisting of five levels of Nitrogen $\left(0,40,80,120\right.$ and $\left.160 \mathrm{~kg} \mathrm{~N} \mathrm{ha}^{-1}\right)$ and four levels each of phosphorous $(0,40,80$ and 120 $\left.\mathrm{kg} \mathrm{P}_{2} \mathrm{O}_{5} \mathrm{ha}^{-1}\right)$, potassium $\left(0,30,60\right.$ and $\left.90 \mathrm{~kg} \mathrm{~K}_{2} \mathrm{O} \mathrm{ha}{ }^{-1}\right)$ and sulfur $\left(0,10,20\right.$ and $\left.30 \mathrm{~kg} \mathrm{~S} \mathrm{ha}^{-1}\right)$, three levels each of zinc $\left(0,4\right.$ and $\left.8 \mathrm{~kg} \mathrm{ha}^{-1}\right)$ and boron $\left(0,1\right.$ and $\left.1.5 \mathrm{~kg} \mathrm{~B} \mathrm{ha}^{-1}\right) . \mathrm{N}, \mathrm{P}, \mathrm{K}, \mathrm{S}, \mathrm{Zn}$ and $B$ were given in the form urea, TSP, MOP, gypsum, zinc oxide and boric acid. The 19 treatmentwise fertilizer combinations are given in Table 2.

Table 1. Some physical and chemical properties of the soil of experimental plots prior to fertilizer application

\begin{tabular}{|c|c|c|c|c|c|c|c|c|c|c|c|c|c|}
\hline \multirow{2}{*}{ Year } & \multirow{2}{*}{ Texture } & \multirow{2}{*}{$\mathrm{pH}$} & \multirow{2}{*}{ OM\% } & \multicolumn{3}{|c|}{ meq $100 \mathrm{~g}^{-1}$} & \multicolumn{7}{|c|}{$\mu g^{-1}$} \\
\hline & & & & $\mathrm{Ca}$ & $\mathrm{Mg}$ & $\mathrm{K}$ & $\mathrm{NH} 4-\mathrm{N}$ & $\mathrm{P}$ & $\mathrm{S}$ & B & $\mathrm{Cu}$ & $\mathrm{Mn}$ & $\mathrm{Zn}$ \\
\hline $2005-2006$ & $\begin{array}{c}\text { Sandy clay } \\
\text { loam }\end{array}$ & 5.7 & 0.98 & 2.8 & 1.4 & 0.16 & 0.17 & 19 & 15 & 0.2 & 8 & 40 & 2.1 \\
\hline 2006-2007 & $\begin{array}{c}\text { Sandy clay } \\
\text { loam }\end{array}$ & 5.5 & 0.92 & 2.4 & 1.5 & 0.23 & 0.16 & 17 & 14 & 0.2 & 8 & 42 & 2.1 \\
\hline $\begin{array}{c}\text { Critical } \\
\text { level }\end{array}$ & - & - & - & 2.0 & 0.8 & 0.2 & 75 & 14 & 14 & 0.2 & 1 & 33 & 2 \\
\hline
\end{tabular}


Table 2. Effect of N P K S Zn and B on growth characters of French bean (var. BARI Jhar Shim-2)

\begin{tabular}{|c|c|c|c|c|c|c|c|c|c|c|c|c|}
\hline \multirow{2}{*}{$\begin{array}{c}\text { Treatment } \\
\text { code }\end{array}$} & \multicolumn{6}{|c|}{ Treatment combination $\left(\mathrm{kg} \mathrm{ha}^{-1}\right)$} & \multicolumn{2}{|c|}{ Plant height $(\mathrm{cm})$} & \multicolumn{2}{|c|}{ Branches per plant(no.) } & \multicolumn{2}{|c|}{ Leaves per plant (no.) } \\
\hline & $\mathrm{N}$ & $\mathrm{P}_{2} \mathrm{O}_{5}$ & $\mathrm{~K}_{2} \mathrm{O}$ & $\mathrm{S}$ & $\mathrm{Zn}$ & $B$ & $2005-2006$ & $2006-2007$ & $2005-2006$ & 2006-2007 & $2005-2006$ & $2006-2007$ \\
\hline $\mathrm{T}_{1}$ & 0 & 0 & 0 & 0 & 0 & 0 & $28.73 g$ & $30.00 \mathrm{~g}$ & $4.84 \mathrm{~g}$ & $4.13 e$ & $9.80 \mathrm{~h}$ & 10.06h \\
\hline $\mathrm{T}_{2}$ & 0 & 80 & 60 & 20 & 4 & 1 & $29.33 f g$ & $30.20 \mathrm{~g}$ & $5.50 \mathrm{~d}-\mathrm{g}$ & 4.33de & $10.69 \mathrm{~g}$ & $11.44 \mathrm{~g}$ \\
\hline $\mathrm{T}_{3}$ & 40 & 80 & 60 & 20 & 4 & 1 & $30.08 \mathrm{efg}$ & $30.67 \mathrm{~g}$ & $5.60 \mathrm{c}-\mathrm{g}$ & 4.47cde & $11.02 \mathrm{fg}$ & $12.03 f g$ \\
\hline $\mathrm{T}_{4}$ & 80 & 80 & 60 & 20 & 4 & 1 & $31.55 b-e$ & 38.27gef & $5.86 c-f$ & $5.27 \mathrm{~b}-\mathrm{e}$ & $12.82 \mathrm{bc}$ & $14.09 a-d$ \\
\hline$T_{5}$ & 120 & 80 & 60 & 20 & 4 & 1 & 33.60a & 43.93abc & 6.20a-d & 6.27ab & 13.18b & $14.50 \mathrm{abc}$ \\
\hline $\mathrm{T}_{6}$ & 160 & 80 & 60 & 20 & 4 & 1 & $33.76 a$ & $46.13 a$ & 6.30a-d & $5.93 b$ & $13.01 b c$ & $14.41 \mathrm{abc}$ \\
\hline $\mathrm{T}_{7}$ & 120 & 0 & 60 & 20 & 4 & 1 & 31.10cde & $36.73 f$ & 5.35efg & $5.67 \mathrm{bcd}$ & $12.29 \mathrm{~cd}$ & 13.57cde \\
\hline $\mathrm{T}_{8}$ & 120 & 40 & 60 & 20 & 4 & 1 & 30.72def & $36.47 f$ & $5.80 c-f$ & $5.73 b c$ & $12.89 b c$ & 14.19abc \\
\hline $\mathrm{T}_{9}$ & 120 & 120 & 60 & 20 & 4 & 1 & $33.74 a$ & 41.47b-e & 6.32abc & 5.33b-e & $13.93 a$ & $15.26 \mathrm{a}$ \\
\hline $\mathrm{T}_{10}$ & 120 & 80 & 0 & 20 & 4 & 1 & $31.20 \mathrm{cde}$ & 37.47 ef & $5.84 c-f$ & 6.40ab & 12.62ef & 12.83 ef \\
\hline $\mathrm{T}_{11}$ & 120 & 80 & 30 & 20 & 4 & 1 & $32.15 a-d$ & 43.93abc & $5.88 c-f$ & $6.40 \mathrm{ab}$ & $13.02 b$ & $14.38 \mathrm{abc}$ \\
\hline $\mathrm{T}_{12}$ & 120 & 80 & 90 & 20 & 4 & 1 & $33.46 a$ & 43.53abc & 6.83ab & $5.93 b$ & $13.26 \mathrm{~b}$ & 14.73abc \\
\hline $\mathrm{T}_{13}$ & 120 & 80 & 60 & 0 & 4 & 1 & $32.70 a-d$ & 43.87abc & $5.93 c-f$ & $5.40 \mathrm{~b}-\mathrm{e}$ & $12.58 \mathrm{bc}$ & $13.90 \mathrm{~b}-\mathrm{e}$ \\
\hline $\mathrm{T}_{14}$ & 120 & 80 & 60 & 10 & 4 & 1 & 33.23ab & 44.93ab & $6.20 \mathrm{a}-\mathrm{d}$ & 6.60ab & $13.01 b c$ & $14.42 \mathrm{abc}$ \\
\hline $\mathrm{T}_{15}$ & 120 & 80 & 60 & 30 & 4 & 1 & $32.73 a b c$ & 40.00c-f & $5.13 \mathrm{fg}$ & $5.87 b$ & 11.69de & 12.91def \\
\hline $\mathrm{T}_{16}$ & 120 & 80 & 60 & 20 & 0 & 1 & $32.80 \mathrm{abc}$ & $40.17 c-f$ & $5.92 c-f$ & 6.23ab & $12.63 \mathrm{bc}$ & 13.94b-e \\
\hline $\mathrm{T}_{17}$ & 120 & 80 & 60 & 20 & 8 & 1 & 33.33a & 40.17c-f & 6.18a-d & 6.37ab & $13.00 \mathrm{bc}$ & $14.36 \mathrm{abc}$ \\
\hline $\mathrm{T}_{18}$ & 120 & 80 & 60 & 20 & 4 & 0 & 33.20ab & 38.87def & $6.70 b-e$ & $5.60 \mathrm{bcd}$ & $12.87 \mathrm{bc}$ & $14.24 \mathrm{abc}$ \\
\hline $\mathrm{T}_{19}$ & 120 & 80 & 60 & 20 & 4 & 1.5 & $33.80 a$ & $42.27 a-d$ & $6.91 a$ & $7.33 a$ & $13.15 b$ & 14.76ab \\
\hline \multicolumn{7}{|c|}{ CV (\%) } & 2.83 & 3.61 & 6.97 & 7.42 & 3.07 & 2.75 \\
\hline
\end{tabular}

Means showing different letters in a column within a year are significantly different at $5 \%$ level of probability by DMRT.

A blanket dose of golybdenum (0.5 $\mathrm{kg} \mathrm{ha}^{-1}$ from sodium-molybdate) and cowdung (10 $\left.\mathrm{t} \mathrm{ha}^{-1}\right)$ was used. The total amount of cowdung, TSP, and MP, gypsum, zinc oxide, boric acid, sodiummolybdate and one-half quantity of urea was applied prior to planting seeds and the remaining quantity of urea was applied 25 days after sowing as side dressing.

Seeds of the variety BARI French bean-2 were dibbled being 2 seeds/hill on 26 and 22 December of 2005 and 2006, respectively, maintaining plant spacing of $20 \times 10 \mathrm{~cm}$. The unit plot was $3.0 \times 1.2 \mathrm{~m}$. After 15 days of sowing when the germination was completed, thinning was done leaving one seedling in each site In addition to pre-sowing irrigation; four additional irrigations were given to the crop. All the recommended cultural and plant protection measures were followed throughout the experimental period. Tender green pods were picked at regular intervals from an area of $3.6 \mathrm{~m}^{2}$ for recording plot yield of the total five pickings.

The data on plant height at $1^{\text {st }}$ flowering, number of branches per plant, number of trifoliate leaves per plant, pod length, pod width, number of green pods per plant and green pod weight per plant were recorded from randomly selected 10 plants of the inner rows. The plot yield was converted to per hectare yield.

The optimum and economic doses of $\mathrm{N}, \mathrm{K}$ and $\mathrm{S}$ for maximum green pod yield was calculated from simple polynomial regression equation i.e. $Y=\alpha+\beta_{1} X+\beta_{2} X^{2}$ (Zaman et al., 1982). Here $X$ is the independent variable (fertilizer) and $Y$ is the dependent variable (pod yield). The optimum dose of fertilizer for maximum yield was $X=-\beta_{1} / 2 \beta_{2}$. The data were analyzed through MSTAT Program and the treatment means were separated by DMRT at $5 \%$ level of probability for interpretation of the results.

\section{RESULTS AND DISCUSSION}

\section{Plant height}

Plant height was significantly influenced by different fertilizer treatments (Table 2). In 2005-2006 the highest plant height at $1^{\text {st }}$ flowering recorded in $T_{19}$ treatment which was superior to $T_{1}, T_{2}, T_{3}$, $T_{4}, T_{7}, T_{8}$ and $T_{10}$ treatments but at par with the remaining treatments, while in 2006-2007 


\section{Moniruzzaman et al.}

maximum plant height was recorded in $T_{6}$ treatment which was statistically identical to $T_{5}, T_{11}, T_{12}$, $\mathrm{T}_{13}$ and $\mathrm{T}_{19}$ treatments. The lowest plant height at $1^{\text {st }}$ flowering was obtained from control treatment $\left(T_{1}\right)$. Nitrogen helps in chlorophyll formation, $\mathrm{P}$ establishes strong root system, $\mathrm{K}$ and $\mathrm{B}$ helps in translocation of photosynthates, $\mathrm{Zn}$ helps in auxin synthesis. Therefore their integrated actions increased plant height. Application of $\mathrm{N}$ irrespective of other fertilizer nutrient significantly influenced plant height at $1^{\text {st }}$ flowering (Table 2). Plant height was significantly increased up to 120 $\mathrm{kg} \mathrm{N} \mathrm{ha}^{-1}$ in both years. Although $160 \mathrm{~kg} \mathrm{~N} \mathrm{ha}^{-1}$ increased plant height, there was no significant difference between 120 and $160 \mathrm{~kg} \mathrm{~N} \mathrm{ha}^{-1}$. During both years plant height was significantly increased up to $80 \mathrm{~kg} \mathrm{P}_{2} \mathrm{O}_{5} \mathrm{ha}^{-1}$. Although application of phosphorus at the highest level $(120 \mathrm{~kg}$ $\mathrm{P}_{2} \mathrm{O}_{5} \mathrm{ha}^{-1}$ ) increased plant height, no significant difference was observed between 80 and $120 \mathrm{~kg}$ $\mathrm{P}_{2} \mathrm{O}_{5}$ ha $^{-1}$ in the first year and in the $2^{\text {nd }}$ year, when $\mathrm{P}$ was applied @ $120 \mathrm{~kg} \mathrm{P}_{2} \mathrm{O}_{5}$ ha $^{-1}$ decreased plant height significantly. Amount of $\mathrm{N}$ beyond optimum level brings about nutrient imbalance and suppressed growth of the plant and excess $\mathrm{P}$ level causes reduction in vegetative growth. The similar effect of $N$ and $P$ on plant height was reported by Srinivas and Naik (1990). All the levels of potassium increased plant height but no significant difference was observed among 30,60 and 90 $\mathrm{kg} \mathrm{K}_{2} \mathrm{O} \mathrm{ha}^{-1}$. Application of $\mathrm{S}$ did not significantly influence plant height in both years while in the $2^{\text {nd }}$ year, $\mathrm{S}$ application at higher dose $\left(30 \mathrm{~kg} \mathrm{ha}^{-1}\right)$ decreased plant height significantly. There is little effect on plant height due to $\mathrm{Zn}$ and $\mathrm{B}$ application in both years.

\section{Number of branches}

Number of branches per plant was significantly influenced due to fertilizer treatments during both years (Table 2). Maximum branches per plant was recorded in $T_{19}$ treatment, in both years, which was at par with $T_{5}, T_{6}, T_{9}, T_{12}, T_{14}$ and $T_{17}$ in the first year and in the second year with $T_{5}, 7_{10}, T_{11}$, $\mathrm{T}_{14}, \mathrm{~T}_{16}, \mathrm{~T}_{17}$, and $\mathrm{T}_{18}$ treatments. Branches per plant increased significantly with the increase of $\mathrm{N}$ up to $120 \mathrm{~kg} \mathrm{~N} \mathrm{ha}^{-1}$ in both years (Table 2). Although branches per plant increased up to $160 \mathrm{~kg} \mathrm{ha}^{-}$ 1 in 2005-2006, this parameter was decreased at $160 \mathrm{~kg} \mathrm{~N} \mathrm{ha}^{-1}$ in 2006-2007; there was no significant difference between 120 and $160 \mathrm{~kg} \mathrm{~N} \mathrm{ha}^{-1}$ in any of the years in respect of number of branches per plant. Branches per plant increased up to $80 \mathrm{~kg} \mathrm{P}_{2} \mathrm{O}_{5} \mathrm{ha}^{-1}$ in both years with no significant difference between 80 and $120 \mathrm{~kg} \mathrm{P}_{2} \mathrm{O}_{5} \mathrm{ha}^{-1}$. The results of $\mathrm{N}$ and $\mathrm{P}$ are in agreement with Srinivas and Naik (1990). Dhanjal et al. (2001) found significantly higher branches per plant at $120 \mathrm{~kg} \mathrm{~N}^{-1}$ Application of $60 \mathrm{~kg} \mathrm{~K}_{2} \mathrm{O}, 10 \mathrm{~kg} \mathrm{~S}, 4 \mathrm{~kg} \mathrm{Zn}$ and $1 \mathrm{~kg} \mathrm{~B} \mathrm{ha}^{-1}$ significantly influenced number of branches per plant in 2005-2006, but no significant influence was observed in respect of branches per plant due to K, S, Zn and B application in 2006-2007. Potassium and S enhanced the formation of chlorophyll and encouraged vegetative growth while $\mathrm{Zn}$ promotes biosynthesis of auxin and $\mathrm{B}$ helps in $\mathrm{N}$ absorption. Therefore, their combined actions increased number of branches per plant.

\section{Number of leaves}

Number of leaves per plant was significantly influenced by the application of fertilizer (Table 2). Significantly highest plant height was recorded in $\mathrm{T}_{9}$ treatment (both years), which was superior to all other treatments in $1^{\text {st }}$ year and statistically identical to $T_{4}, T_{5}, T_{6}, T_{8}, T_{11}, T_{12}, T_{14}, T_{17}, T_{18}, T_{19}$ in $2^{\text {nd }}$ year. Number of leaves was significantly increased up to $80 \mathrm{~kg} \mathrm{~N} \mathrm{ha}^{-1}$ with no significant difference among 80, 120 and $160 \mathrm{~kg} \mathrm{~N}$ ha $^{-1}$ (Table 2). Application of phosphorus @ 40, 80 and $120 \mathrm{~kg} \mathrm{P}_{2} \mathrm{O}_{5} \mathrm{ha}^{-1}$ increased number of leaves per plant compared to control but no significant difference was observed among 40, 80 and $120 \mathrm{~kg} \mathrm{P}_{2} \mathrm{O}_{5} \mathrm{ha}^{-1}$. Number of leaves per plant was increased due to the application of $\mathrm{K}, \mathrm{S}, \mathrm{Zn}$ and $\mathrm{B}$ compared to control in both years but there was no significant difference among higher doses each of $\mathrm{K}, \mathrm{S}, \mathrm{Zn}$ and $\mathrm{B}$. Nitrogen and $\mathrm{K}$ promotes chlorophyll formation and $\mathrm{P}$ helps in nutrient absorption by lateral root development. As a result number of leaves per plant increased.

\section{Pod length and pod width}

Maximum pod length was recorded in $T_{19}$ (2005-2006) and in $T_{9}$ (2006-2007), which was at par with $T_{5}, T_{9}$ and $T_{12}$ in first year and superior to $T_{1}, T_{2}, T_{3}, T_{4}, T_{7}$ and $T_{13}$ treatments in second year (Table 3). The minimum pod length was obtained from $T_{1}$ treatment in both years. Pod length increased with the increase of $\mathrm{N}$ up to $120 \mathrm{~kg} \mathrm{~N} \mathrm{ha}^{-1}$ beyond which pod length declined in both 
years (Table 3). Optimum level of $N\left(120 \mathrm{~kg} \mathrm{ha}^{-1}\right)$ increases the rate of photosynthesis by chlorophyll formation and thus more ptoassimilates were made and pod length increased. However when $\mathrm{N}$ was applied @ $160 \mathrm{~kg} \mathrm{ha}^{-1}, \mathrm{~N}$ increased vegetative growth instead of pod development. Singh (2000) got maximum pod length from the application of $125 \mathrm{~kg} \mathrm{~N} \mathrm{ha}^{-1}$ which was at par with 100 and $75 \mathrm{~N} \mathrm{ha}^{-1}$. Potassium application increased pod length up to its highest level but no significant difference was observed between 80 and $120 \mathrm{~kg} \mathrm{P}_{2} \mathrm{O}_{5} \mathrm{ha}^{-1}$ during both years. Pod length was increased significantly up to $60 \mathrm{~kg} \mathrm{~K}_{2} \mathrm{O} \mathrm{ha}^{-1}$ in 2005-2006 while no significant influence was observed due to $\mathrm{K}$ application in 2006-2007. Phosphorus helped in developing flowers and fruits and $\mathrm{K}$ maintains balance between $\mathrm{N}$ and $\mathrm{P}$. In first year, maximum pod length was observes at 20 $\mathrm{kg} \mathrm{S} \mathrm{ha}^{-1}$ but at $10 \mathrm{~kg} \mathrm{~S} \mathrm{ha}^{-1}$ in $2^{\text {nd }}$ year. Application of $\mathrm{Zn}$ and B significantly increased pod length up to $4 \mathrm{~kg} \mathrm{Zn}$ and $1.0 \mathrm{~kg} \mathrm{~B} \mathrm{ha}^{-1}$ in 2005-2006, but no significant influence was noticed due to $\mathrm{Zn}$ and B application in 2006-2007. Pod width was significantly influenced in 2005-2006 (Table 3). Maximum pod width was recorded in $T_{19}$ treatment which was at par with $T_{5}, T_{9}, T_{12}$ and $T_{18}$ treatment.

\section{Table 3. Effect of N P K S Zn and B on yield attributes and yield of French bean (var. BARI Jhar Shim-2)}

\begin{tabular}{|c|c|c|c|c|c|c|c|c|c|c|}
\hline $\begin{array}{l}\text { reatment } \\
\text { code }\end{array}$ & Pod length $(\mathrm{cm})$ & Pod widt & th $(\mathrm{cm}$ & $\begin{array}{l}\text { Green } \\
\text { plan }\end{array}$ & $\begin{array}{l}\text { pods per } \\
\text { tt (no.) }\end{array}$ & $\begin{array}{r}\text { Green p } \\
\text { per pl }\end{array}$ & $\begin{array}{l}\text { od weight } \\
\text { lant (g) }\end{array}$ & Gre & not is & 1) \\
\hline & -0620 & $5-$ & 2 & 2005-06 & $2006-07$ & 2005-06 & $2006-07$ & $2005-06$ & 200 & Pooled \\
\hline $\mathrm{T}_{1}$ & $3 \mathrm{~h} \quad 11$ & 0 & & & & & & & & \\
\hline $\mathrm{T}_{2}$ & 1. & & & 12. & $13 . c$ & & & & & \\
\hline$T_{3}$ & 11.63fgh 11.9 & & & $16.70 f$ & $16.83 f$ & $65.93 b$ & & & & \\
\hline $\mathrm{T}_{4}$ & 1 & & 0.75 & 20.6 & $20.67 b-e$ & 81.2 & 83.10gh & $h$ & & \\
\hline$T_{5}$ & & & 0.77 & 24 & $24.77 a$ & 95 & 10 & 22. & & \\
\hline $\mathrm{T}_{6}$ & & & 0.77 & 21.9 & $22.00 \mathrm{abc}$ & c $89.00 \mathrm{~cd}$ & 103.3bc & 21. & & \\
\hline $\mathrm{T}_{7}$ & & & 0.75 & 19. & 19. & 74. & $61 \mathrm{i}$ & & & \\
\hline $\mathrm{T}_{8}$ & & & 0.75 & 22. & 22.6 & 83.83ef & 102 & & & \\
\hline$T_{9}$ & & & & & & & & & & \\
\hline $\mathrm{T}_{10}$ & & & & & & & & & & \\
\hline $\mathrm{T}_{11}$ & & & & 18. & 18. & & & & & \\
\hline 10 & & & & 25. & & & & & & \\
\hline & & & & & & & & & & \\
\hline & 1 & & & 17 & 17. & 84.2 & & 19 & & \\
\hline$T_{15}$ & 1 & & & 17. & 17.8 & 81 & 86 & & & \\
\hline$T_{1}$ & 12 & & 0 & 19.4 & 19. & 83. & $2 \mathrm{gh}$ & & 19 & \\
\hline & & & & 20.8 & & & 96 & & & \\
\hline & & & & 22. & & 87. & $97 \quad$ & 21. & & \\
\hline & Jc & & & 24 & 23.8 & 109 & 89.68efg & $24.48 a$ & 19.05de & $21.77 a-d$ \\
\hline & 4.2 & & & & & & & & T.V & \\
\hline
\end{tabular}

Means showing different letters in a column within a year are significantly different at $5 \%$ level of probability by DMRT. Details of treatment combinations were given in Table 2.

\section{Number of green pods}

Different levels of N, P, K, S, Zn and B significantly affected the number of green pods per plant in both years (Table 3 ). The highest number of green pods per plant was recorded in $T_{5}$ treatment in both the years. In the first year, the $T_{5}$ treatment was superior to all the treatments except $T_{9}, T_{12}$, and $T_{19}$ treatments in 2005-2006 and in $2^{\text {nd }}$ year except $T_{6}, T_{8}, T_{9}, T_{12}, T_{18}$ and $T_{19}$ treatments. During both years number of pods per plant increased with increasing $N$ up to $120 \mathrm{~kg} \mathrm{~N}^{-1}$ beyond which it declined. In case of $\mathrm{P}$, number of pods per plant was increased up to $120 \mathrm{~kg} \mathrm{P}_{2} \mathrm{O}_{5}$ $\mathrm{ha}^{-1}$ in 2005-2006 and up to $80 \mathrm{~kg} \mathrm{P}_{2} \mathrm{O}_{5} \mathrm{ha}^{-1}$ in 2006-2007. There was no significant difference observed between 80 and $120 \mathrm{~kg} \mathrm{P}_{2} \mathrm{O}_{5} \mathrm{ha}^{-1}$ in the first year and between 40 and $80 \mathrm{~kg} \mathrm{P}_{2} \mathrm{O}_{5} \mathrm{ha}^{-1}$ in 2006-2007. The results influenced by $N$ and $P$ are in consonance with Srinivas and Naik (1990), Rana and Singh (1998) and Baboo et al. (1998). Singh (2000) obtained significantly maximum pod at $100 \mathrm{~kg} \mathrm{~N} \mathrm{ha}^{-1}$ compared to $125 \mathrm{~kg} \mathrm{~N} \mathrm{ha}^{-1}$. Dahatonde and Nalamwar (1996) reported that 


\section{Moniruzzaman et al.}

application of $\mathrm{N} @ 120 \mathrm{~kg} \mathrm{ha}^{-1}$ produced maximum number of pods per plant that was statistically similar to $90 \mathrm{~kg} \mathrm{~N} \mathrm{ha}^{-1}$. Number of pods per plant increased up to $90 \mathrm{~kg} \mathrm{~K}_{2} \mathrm{O} \mathrm{ha}^{-1}$ with no significant difference between 60 and $90 \mathrm{~kg} \mathrm{~K}_{2} \mathrm{O} \mathrm{ha}^{-1}$ in 2005-2006. But in 2006-2007 pods per plant increased up to $60 \mathrm{~kg} \mathrm{~K}_{2} \mathrm{O}$ ha $^{-1}$ and further increase in $\mathrm{K}$ level did not increase pods per plant although no significant difference was noticed between 60 and $90 \mathrm{~kg} \mathrm{~K}_{2} \mathrm{O} \mathrm{ha}{ }^{-1}$. Pod per plant were increased up to $20 \mathrm{~kg} \mathrm{~S}, 4 \mathrm{~kg} \mathrm{Zn}$ in both years beyond which number of pods declined. In 20052006 pod number increased up to $1.5 \mathrm{~kg} \mathrm{~B} \mathrm{ha}^{-1}$ while in 2006-2007 up to $1.0 \mathrm{~kg} \mathrm{~B} \mathrm{ha}^{-1}$.

\section{Green pod weight}

A significant difference in green pod weight per plant was obtained with different rates of N P K S $\mathrm{Zn}$ and $\mathrm{B}$ during both years (Table 3 ). The highest green pod weight per plant recorded in $\mathrm{T}_{19}$ treatment which was significantly different from other treatments in 2005-2006. But in 2006-2007, maximum green pod weight per plant was obtained from $T_{9}$ treatment closely followed by $T_{5}$ treatment. The minimum green pod weight per plant was obtained from control treatment $\left(T_{1}\right)$ in both years. Green pod weight per plant increased significantly with the increase of N up to $120 \mathrm{~kg}$ $\mathrm{N}$ ha $^{-1}$ beyond which green pod weight decreased in both years (Table 3 ). The results are in agreement with Srinivas and Naik (1990). Singh (2000) reported that pod weight per plant was maximum at $125 \mathrm{~kg} \mathrm{~N} \mathrm{ha}^{-1}$ with no significant difference at $100 \mathrm{~kg} \mathrm{~N} \mathrm{ha}^{-1}$. Similar response was also observed in case of $\mathrm{P}$ application only in 2005-2006 but in 2006-2007 green pod weight was increased up to $120 \mathrm{~kg} \mathrm{P}_{2} \mathrm{O}_{5}$ ha $^{-1}$ with no significant difference between 80 and $120 \mathrm{~kg} \mathrm{P}_{2} \mathrm{O}_{5} \mathrm{ha}^{-1}$. Srinivas and Naik (1990) observed no significant difference between 40 and $80 \mathrm{~kg} \mathrm{P}_{2} \mathrm{O}_{5} \mathrm{ha}^{-1}$ and reported $143.33 \mathrm{~kg} \mathrm{P}_{2} \mathrm{O}_{5} \mathrm{ha}^{-1}$ as optimum dose for French bean production in Bengalore. Application of $\mathrm{K}$ increased green pod weight per plant up to its higher level $\left(90 \mathrm{~kg} \mathrm{~K}_{2} \mathrm{O} \mathrm{ha}^{-1}\right)$ in 2005-06 but in 2006-07, green pod weight per plant was significantly declined at $90 \mathrm{~kg} \mathrm{~K}_{2} \mathrm{O}$ ha ${ }^{-1}$ compared to $60 \mathrm{~kg} \mathrm{~K}_{2} \mathrm{O} \mathrm{ha}^{-1}$. In both years, green pod weight per plant increased significantly up to $20 \mathrm{~kg} \mathrm{~S} \mathrm{ha}^{-1}$ but further increase in S level did not increase pod weight per plant. Green pod weight per plant was significantly highest at $4 \mathrm{~kg} \mathrm{Zn} \mathrm{ha}^{-1}$ in both years. In case of B application, pod weight per plant increased significantly up to $1.5 \mathrm{~kg} \mathrm{~B} \mathrm{ha}^{-1}$ in 2005-2006 but in 2006-2007 pod weight increased up to $1.0 \mathrm{~kg} \mathrm{~B} \mathrm{ha}^{-1}$ beyond which it declined.

\section{Green pod yield}

Significant increase in green pod yield was observed with different fertilizer treatment in both years as well as in pooled data (Table 3). In 2005-2006, the highest green pod yield ha ${ }^{-1}$ recorded with $T_{19}$ treatment, which was at par with $T_{5}, T_{9}$ and $T_{12}$ treatment but in 2006-2007, maximum pod yield was obtained from $T_{5}$ treatment closely followed by $T_{9}, T_{11}$ and $T_{18}$ treatments. Pooled analysis showed that the highest yield was obtained from $T_{9}$ treatment which was at par with $T_{5}, T_{11}, T_{12}, T_{18}$ and $T_{19}$ treatments. The lowest pod yield per hectare was recorded in control treatment $\left(T_{1}\right)$ in both years and pooled data. In pooled data, green pod yield increased significantly with increasing $\mathrm{N}$ rate up to $120 \mathrm{~kg} \mathrm{~N}^{-1}$ beyond which yield decreased (Table 3; Figure 1.A). Application of $\mathrm{N}$ at $120 \mathrm{~kg} \mathrm{~N} \mathrm{ha}{ }^{-1}$ produced significantly maximum pod size (pod length $\mathrm{x}$ pod width), number of green pods per plant and green pod weight per plant than that of $160 \mathrm{~kg} \mathrm{~N} \mathrm{ha}^{-1}$ which resulted the highest pod yield from the treatment. Pod yield increased by 30.42, 52.50, 86.97 and $65.33 \%$ over control due to application of $40,80,120$ and $160 \mathrm{~kg} \mathrm{~N} \mathrm{ha}^{-1}$, respectively (Table 4). Highest yield might be due to the fact that $\mathrm{N}$ is an integral part of chlorophyll and play a vital role in photosynthesis and carbohydrate production. Singh (2000) and Srinivas and Naik (1990) obtained the highest yield of pod at 125 and $120 \mathrm{~kg} \mathrm{~N}^{-1}$, respectively. BARI (2004) reported that application of $\mathrm{N} @ 150 \mathrm{~kg} \mathrm{~N}$ $\mathrm{ha}^{-1}$ produced significantly higher pod yield of BARI Jhar Shim-1 that was at par with $200 \mathrm{~kg} \mathrm{~N} \mathrm{ha}^{-1}$. Projapoti et al. (2004) also recorded higher pod yield of French bean from $120 \mathrm{~kg} \mathrm{~N} \mathrm{ha}^{-1}$. Pooled yield reveled that pod yield increased gradually with the increase of $P$ up to $120 \mathrm{~kg} \mathrm{P}_{2} \mathrm{O}_{5}$ ha $^{-1}$ with no significant difference between two higher doses (80 and $120 \mathrm{~kg} \mathrm{P}_{2} \mathrm{O}_{5} \mathrm{ha}^{-1}$ ). Phosphorus application @ $120 \mathrm{~kg} \mathrm{P}_{2} \mathrm{O}_{5} \mathrm{ha}^{-1}$ performed better than that of $80 \mathrm{~kg} \mathrm{P}_{2} \mathrm{O}_{5} \mathrm{ha}^{-1}$ in respect of all yield

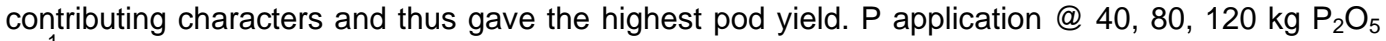
$\mathrm{ha}^{-1}$ increased pod yield of French bean by $14.95,23.11$ and $23.14 \%$, respectively, over control. The pod yield of French bean increased by $80 \mathrm{~kg} \mathrm{P}_{2} \mathrm{O}_{5}$ ha $^{-1}$ application was very close to that of $120 \mathrm{~kg} \mathrm{P}_{2} \mathrm{O}_{5} \mathrm{ha}^{-1}$ over control. Srinivas and Naik (1990) reported that significantly highest pod yield 
was recorded at $80 \mathrm{~kg} \mathrm{P}_{2} \mathrm{O}_{5} \mathrm{ha}^{-1}$. BARI (2004) got pod yield in response of the variety, BARI Jhar Shim-1 up to $60 \mathrm{~kg} \mathrm{P}\left(137.4 \mathrm{~kg} \mathrm{P}_{2} \mathrm{O}_{5}\right.$ ha $\left.^{-1}\right)$ with no significant difference with application of $40 \mathrm{~kg} \mathrm{P}$ $\left(91.6 \mathrm{~kg} \mathrm{P}_{2} \mathrm{O}_{5} \mathrm{ha}^{-1}\right)$. Pod yield increased up to $60 \mathrm{~kg} \mathrm{~K}_{2} \mathrm{O} \mathrm{ha}^{-1}$ and further increase in $\mathrm{K}$ decreased pod yield (Figure 1. C). Sulfur, Zn and B also showed similar effect of K. Application of S, Zn and B @ 20, 4 and $1 \mathrm{~kg} \mathrm{ha}^{-1}$, respectively increased pod yield by $25.83,16.01$ and $2.48 \%$ over control (Table 4) and further increase in levels of each S, Zn and B decreases pod yield (Table 4).

Table 4. Single effect of N, P, K, S, Zn and B on green pod yield (pooled) of French bean

\begin{tabular}{|c|c|c|c|c|c|}
\hline $\begin{array}{l}\text { Nutrient } \\
\left(\mathrm{kg} \mathrm{ha}^{-1}\right)\end{array}$ & $\begin{array}{l}\text { Average green } \\
\text { pod yield }\left(\mathrm{t} \mathrm{ha}^{-1}\right)\end{array}$ & $\begin{array}{c}\text { Yield increase } \\
\text { over control (\%) }\end{array}$ & Nutrient $\left(\mathrm{kg} \mathrm{ha}^{-1}\right)$ & $\begin{array}{l}\text { Average green } \\
\text { pod yield }\left(\mathrm{t} \mathrm{ha}^{-1}\right)\end{array}$ & $\begin{array}{l}\text { Yield increase } \\
\text { over control (\%) }\end{array}$ \\
\hline \multicolumn{2}{|c|}{ Nitrogen $\left(\mathrm{kg} \mathrm{N} \mathrm{ha}^{-1}\right)$} & \multicolumn{4}{|c|}{ Sulfur $\left(\mathrm{kg} \mathrm{S} \mathrm{ha}^{-1}\right)$} \\
\hline 0 & 12.36 & - & 0 & 18.41 & - \\
\hline 40 & 16.12 & 30.42 & 10 & 19.22 & 4.40 \\
\hline 80 & 18.83 & 52.50 & 20 & 23.11 & 25.53 \\
\hline 120 & 23.11 & 86.97 & 30 & 19.03 & 3.37 \\
\hline 160 & 20.46 & 65.33 & - & - & - \\
\hline \multicolumn{2}{|c|}{ Phosphorus $\left(\mathrm{kg} \mathrm{P}_{2} \mathrm{O}_{5} \mathrm{ha}^{-1}\right)$} & \multicolumn{4}{|c|}{ Zinc $\left(\mathrm{kg} \mathrm{Zn} \mathrm{ha}^{-1}\right)$} \\
\hline 0 & 16.59 & - & 0 & 19.92 & - \\
\hline 40 & 19.07 & 14.95 & 4 & 23.11 & 16.01 \\
\hline 80 & 23.11 & 23.11 & 8 & 20.16 & 1.20 \\
\hline 120 & 23.14 & 23.14 & - & - & \\
\hline \multicolumn{2}{|c|}{ Potassium $\left(\mathrm{kg} \mathrm{K}_{2} \mathrm{O} \mathrm{ha}^{-1}\right)$} & \multicolumn{4}{|c|}{ Boron $\left(\mathrm{kg} \mathrm{B} \mathrm{ha}^{-1}\right)$} \\
\hline 0 & 20.35 & - & 0 & 22.55 & - \\
\hline 30 & 22.62 & 11.40 & 1 & 23.11 & 2.48 \\
\hline 60 & 23.11 & 13.56 & 1.5 & 21.76 & $(-) 3.50$ \\
\hline 90 & 12.93 & 12.68 & - & - & - \\
\hline
\end{tabular}

\section{Response equations}

Regression analyses were done to quantify the relationship of applied N, P, K and S with pod yield. Applied N, P, K and S showed a quadratic relationship with pod yield (Figure 1). Pod yield response of French bean to applied N, P, K and S can be described by the equations $\mathrm{Y}=11.929+$ $0.1386 \mathrm{~N}-0.0005 \mathrm{~N}^{2}, \mathrm{Y}=16.312+0.1052 \mathrm{P}-0.0004 \mathrm{P}^{2}, \mathrm{Y}=20.406+0.0887 \mathrm{~K}-0.0007 \mathrm{~K}^{2}$ and $\mathrm{Y}=17.858+0.4242 \mathrm{~S}-0.0122 \mathrm{~S}^{2}$, respectively (Figure 1). The co-efficient of determinations $\left(\mathrm{R}^{2}=\right.$ 0.9238 for $\mathrm{N}, 0.9501$ for $\mathrm{P}, 0.9876$ for $\mathrm{K}$ ) were significant at $1 \%$ level of probability but $\mathrm{R}^{2}$ for $\mathrm{S}$ (0.5555) was significant at $5 \%$ level of probability. From the response equations the optimum levels of $\mathrm{N}, \mathrm{P}, \mathrm{K}$ and $\mathrm{S}$ were estimated as $138.6,131.5,63.36$ and $17.4 \mathrm{~kg} \mathrm{ha}^{-1}$, respectively. The optimum Zn and B levels were found to be 4 and $1 \mathrm{~kg} \mathrm{~B}$, respectively. The economic doses of $\mathrm{N}, \mathrm{K}$, $\mathrm{P}$ and $\mathrm{S}$ came to be as $135.8,123.3,60.14$ and $17.37 \mathrm{~kg} \mathrm{ha}^{-1}$, respectively.

From the above results and discussion it could be suggested that application of 136-123-6017-4-1 kg of N-P $\mathrm{P}_{2} \mathrm{O}_{5}-\mathrm{K}_{2} \mathrm{O}-\mathrm{S}-\mathrm{Zn}-\mathrm{B} \mathrm{ha}^{-1}$ plus $0.5 \mathrm{~kg} \mathrm{ha}^{-1}$ Mo along with $10 \mathrm{t} \mathrm{ha} \mathrm{H}^{-1}$ cowdung could be the profitable dose for maximizing pod yield of French bean for the variety, BARI Jhar Shim-2 in the South-Eastern Hilly region of Bangladesh (AEZ-29).

\section{LITERATURE CITED}

AVRDC. 1990. "Vegetable Production Training Manual". Asian Vegetable Research and Development Centre, Shanhua, Tainan. 226 pp.

Babbo R., Rana, N. S. and Pantola, P. 1998. Response of French bean (Phaseolus vulgaris L.) to nitrogen and phosphorous. Ann Agric Res 19(1), 81-82.

BARI. 2004. Annual report. Bangladesh Agricultural Research Institute, Gazipur-1701. Bangladesh. pp. 341-342. 
Dahatonde, B. N. and Nalamwar, R. V. 1996. Effect of nitrogen and irrigation level on yield and water use of French bean (Phaseolus vulgaris L.). Indian J Agron 41(2) 265-268.

Dhanjal, R., Prakash, O. and Ahlawat, I. P. S. 2001. Response of French bean (Phaseolus vulgaris L.) varieties to plant density and nitrogen application. Indian J Agron 46(2), 277-281.

Hendrix, J. E. 1967. The effect of $\mathrm{pH}$ on the uptake and accumulation of phosphate and sulphate ions by bean plants. Amer J Bot 54(5), 500-564.

Hunter, A. H. 1984. Soil fertility and analytical services in Bangladesh. BARC/IDAS Cosultancy Report Contract Aid/388-0005. pp. 581-601.

Ivanov, L., Rankov, V., Veler, B., Manuelyan, K. H, Porayajov, I., Benevshi, M. and Petrove, R. 1987. Optimizing mineral fertilization in commercial green bean production. Rasteniev "duiNauk" 24, 45-49.

Lucas, R. E. and Knezek, B. C. 1972. Climate and Soil conditions promoting micronutrient deficiencies in plants. In "Micronutrients in agriculture" (J. J. Mortvedt, P. M. Giordano, and W. L. Lindsay, Eds.), Soil Science Society of America, Madison. pp. 265-268.

Malavolta, E. 1967. "Manual de Quimica Agricola Adubos e Adubacao" (Second Edn.) Agronomica Ceros, Sao Paulo.

Mitra, S. K., Sadhu, M. L. and Bose, T. K. 1990. "Nutrition of Vegetable Crops". Nayaprokash, Calcutta. pp. 157-159.

Parthasharathy, V. A. 1993. French bean. In "Vegetable Crops in India" (T. K. Bose, M. G. Som, and J. Kabir, Eds.), Nayaprokash, Calcutta. pp. 591-602.

Prajapoti, M. P., Patel, H. A., Prajapati, B. A. and Patel, L. R. 2004. Studies of nutrient uptake and yield of French bean (Phaseolus vulgaris L.) as affected by weed control methods and nitrogen levels. Legume Res 27(2), 99-102.

Rana, N. S. and Singh, R. 1998. Effect of nitrogen and phosphorous on growth and yield of French bean (Phaseolus vulgaris L.). Indian J Agron 43(2), 2367-2370.

Singh, R. V. 2000. Response of French bean (Phaseolus vulgaris L.) to plant spacing, and nitrogen, phosphorous fertilization. Indian J Hort 57(4), 338-341.

Srinivas, K. and Naik, L. B. 1990. Growth, yield and nitrogen uptake in vegetable French bean (Phaseolus vulgaris L.) as influenced by nitrogen and phosphorous fertilization. Haryana J Hort Sci 19(1-2), 160-167.

Srinivas, K. and Rao, J. V. 1984. Response of French bean to nitrogen and phosphorous. Indian J Agron 29, 146-149.

Van Schoonhoon, A. and Voysests. O. 1991. "Common Bean: Research for Crop Improvement". CAB International, Oxon. 980 pp. 